\title{
Maine's Spruce Budworm Policy ${ }^{1}$
}

\author{
by
}

\author{
Thomas A. Rumpi²
}

\begin{abstract}
In the 1970s an outbreak of spruce budworm, combined with rising protection costs, environmental concerns, and recoghition of the long-term nature of the infestation, demanded new approaches to forest management and protection. Through adapting traditional policy, frequent conflict and innovation, the Maine Department of Conservation and private landowners refined their understanding of the budworm infestation as a long-term management problem. The recently completed Maine Spruce-Fir Wood Supply/Demand Analysis highlighted the need for investment in more intensive forest management and better wood utilization, in addition to continued protection, if Maine's industries dependent on spruce and fir are to maintain their current levels of production.
\end{abstract}

\section{Résumé}

L'épidémie de la tordeuse des bourgeons de l'épinette, combinée à la montée des coûts de production, les inquiétudes concernant l'environnement ainsi que la prise de conscience face à la durée de l'épidémie ont commandé l'adoption de nouvelles approches en aménagement et en protection de la forêt au cours des années aoixante-dix. C'est par un processus d'adaptation de politiques traditionnelles, de conflits fréquents et d'innovation que le ministère de la Conservation du Maine et les propriétaires fonciers, en sont venus à considérer l'infestation par la tordeuse comme un problème d'aménagement forestier à long terme.

L'analyse d'offre/demande de l'épinette et du sapin du Maine, complétée récemment, a fait ressortir la nécessité d'augmenter les investissements dans un aménagement forestier plus intensif et une utilisation plus grande du bois, en plus d'une protection continue, afin de permettre aux industries qui dépendent de ces essences de maintenir le niveau de production actuel.
Spruce and fir are very important to Maine's export-based timber economy. Nearly half of Maine's 17 million acres (6.9 million hectares) of forest land support spruce and fir (Table 1). More than half of the six million cords of timber harvested annually in Maine are spruce and fir (Table 2). The state's leading manufacturing industry - pulp and paper - depends heavily on this resource. In addition, the spruce-fir lumber industry has expanded significantly since the early 1970's. Maine's forest industry directly provides over 30000 , or one third, of all manufacturing jobs in the state. More than half of

Table 1. Forest area in Maine 1982 (thousands of acs./ha).

\begin{tabular}{lcc}
\hline Type & Acres (hectares) & Percent \\
\hline Spruce/fir & $7.77(3.15)$ & 46 \\
Northern hardwood & $5.00(2.02)$ & 29 \\
Pine & $2.24(.91)$ & 13 \\
Other hardwood & $2.05(.83)$ & 12 \\
\multicolumn{1}{c}{ Total } & $17.06(6.91)$ & $\frac{12}{100}$ \\
\hline
\end{tabular}

A paper given at the International Forest Congress held in Quebec on August 7 , 1984.

2Forest Insect Manager, Maine Forest Service, Station 22, Augusta, Maine 04333

\begin{tabular}{|c|c|c|}
\hline $\begin{array}{l}\text { Species } \\
\text { group }\end{array}$ & $\begin{array}{c}\text { Volume } \\
1000 \text { cu.ft. }\left(1000 \mathrm{~m}^{3}\right) \\
\end{array}$ & $\begin{array}{c}\text { Percent of } \\
\text { total }\end{array}$ \\
\hline $\begin{array}{l}\text { Spruce-fir } \\
\text { Pine \& other softwood } \\
\text { Hardwood }\end{array}$ & $\begin{array}{l}271344(7672) \\
105700(2988) \\
141005(3987) \\
\end{array}$ & $\begin{array}{l}52 \\
20 \\
28\end{array}$ \\
\hline Totals & $518049(14,647)$ & \\
\hline
\end{tabular}

these jobs depend to some degree on the utilization of spruce and fir timber.

Maine began to protect the spruce and fir forest from budworm damage in the 1950's. Since 1972, annual spray programs have been carried out, ranging in size from 430000 to 3500000 acres. The current voluntary state spray program is $100 \%$ financed by participating landowners. In addition to the state program, the Passamaquoddy and Penobscot Indians and two major forest industries have begun their own budworm control programs in recent years. In total, about a quarter of Maine's 7.8 million acres of spruce-fir forest are currently being protected from budworm damage and mortality. To ensure protection, a given acre has required spraying on the average of one out of every two years, since 1974. 


\section{Where are we now?}

In June of 1983 the Maine Spruce-Fir Supply/Demand Analysis was completed. The analysis used the best available information to characterize the current condition of the spruce-fir forest, and then projected the future of that forest under a variety of management, harvest, protection and utilization scenarios.

A note of caution! Modeling the future of any forest is an inexact science at best, and results are best used to compare different strategies rather than to predict absolute outcomes. Given this caution, the analysis provides some clear indications of the potential future: (1) Total volume of spruce and fir is at a peak and will decline in the future given the current age class imbalance of the forest and the combined demands of spruce budworm and our forest economy. Concurrently, spruce-fir stumpage prices are expected to rise significantly in the future as the current oversupply dwindles. (2) Without a strategic combination of timely investments in intensified forest management, better wood utilization, and continued protection of the forest from budworm mortality and growth loss, the current statewide level of spruce-fir harvest is unlikely to be maintained far into the next century.

Wide scale forest regeneration following the budworm outbreak of the teens, and to some extent the selective cutting practices of the past, have created a natural forest dominated by mature stands greater than 50 years old. Over the next 30-40 years this "old forest" will be harvested, and if we act now, gradually transformed into a new managed forest.

The Wood Supply/Demand Analysis pointed out that the actions we choose to take within the next $10-15$ years will determine both the structure and composition of the new forest, and our ability to move into the next century without major disruptions in wood supply.

To ensure that a serious supply shortfall, as envisioned in the analysis, does not materialize, we shall need to undertake three distinct actions: (1) better assessment of the forest resource, (2) strategic individual analyses, and (3) the implementation of investment programs. I shall briefly discuss state initiatives in each of these areas.

First we need better information on the current condition of the forest and the magnitude of potential silvicultural treatment opportunities. The Maine Department of Conservation is preparing a legislative package to request General Fund support for an updated statewide inventory of our spruce and fir resources to answer these questions. The survey will concentrate on determining more precisely how many acres are treatable, and clarifying the current age structure and condition of the forest.

Second, individual mill and landowners need to make detailed strategic analyses to determine which specific interventions, initiated at which specific times, will most effectively alleviate the individual landowner's or mill's potential supply shortfall.

Many landowners have already begun such analyses. To accelerate this process, the Maine Forest Service is funding the refinement of a forest growth model to provide a tool for landowners. We are also initiating a demonstration of this model for wood supply planning in cooperation with the Maine Bureau of Public Lands. Both of these activities will be completed by mid 1985 .
Finally, landowners must move promptly to implement a planned program of investments to take them through a transition in wood supply to a new intensively managed forest. These investments should include a combination of protection, silvicultural actions, and utilization improvements designed to best meet the needs of a given landowner. Management actions initiated during the next $10-15$ years will have the most dramatic effect on future supply during the projected shortfall period. Table 3 summarizes the estimated costs and anticipated yields from several management investments.

Table 3. Yields from alternative silvicultural management regimes in spruce and fir.

\begin{tabular}{lcccc}
\hline $\begin{array}{l}\text { Silvicultural } \\
\text { practice }\end{array}$ & $\begin{array}{c}\text { Estimated } \\
\text { cost } \\
\text { per } \\
\text { acre }\end{array}$ & $\begin{array}{c}\text { Forest } \\
\text { type }\end{array}$ & $\begin{array}{c}\text { Expected } \\
\text { rotation } \\
\text { (years) }\end{array}$ & $\begin{array}{c}\text { Expected } \\
\text { yield at } \\
\text { rotation } \\
\text { (cords/acre)* }\end{array}$ \\
\hline $\begin{array}{l}\text { Commercial } \\
\text { Thinning }\end{array}$ & $\$ 20$ & SW & 60 & $\begin{array}{c}30 \text { (plus 7.5@ } \\
\text { age 40) }\end{array}$ \\
& & MW & 60 & $\begin{array}{c}12 \text { (plus 5.0 @ } \\
\text { age 40) }\end{array}$ \\
$\begin{array}{l}\text { Early composition } \\
\text { control }\end{array}$ & $\$ 50$ & SW & 50 & 35 \\
Density control & $\$ 110$ & MW & 50 & 30 \\
Plantation & $\$ 225$ & MW & 55 & 30 \\
& & SW & 45 & 15 \\
& & MW & 45 & 44 \\
\hline
\end{tabular}

Conversion: 1 cord $/$ acre $=.96 \mathrm{~m} / \mathrm{ha}$

Source: Spruce-Fir Wood Supply/Demand Analysis Final Report, June 1983. Maine Department of Conservation.

Though the Maine Department of Conservations views these investments as primarily a landowner responsibility, the state recognizes the current dilemma of many landowners. Until the current oversupply of mature wood is past, the price of wood will remain artificially low creating a cash flow problem. Many landowners will need assistance in generating capital to make these investments now. The Department of Conservation is developing a proposal for a program of tax credits to encourage landowners to invest in needed sprucefir management practices. We plan to present this package to the Governor's Office for review this fall, in anticipation of submission to the 112th Maine Legislature in January, 1985.

The Main Forest Service will continue to administer the voluntary spruce budworm spray program, pursuing ongoing efforts to maintain the effectiveness of the program while controlling or reducing protection costs. In addition, the Department has initiated a program to develop markets for the products derived from thinning immature softwood stands and to create a market for hardwoods in northern Maine. Markets for this material will expand our potential to carry out intermediate thinning activities economically.

\section{Historical Factors}

Maine's spruce budworm control policy arose in the 1950 's based on the state's successful fire control program. It incorporated a mandatory state-run protection program supported by a tax on all softwood and mixedwood lands. In addition, based on the perception of the budworm outbreak as a short-term and wide-spread emergency, federal and state financial support was provided to cover as much as $75 \%$ of total program costs.

The analogy with fire was appropriate for the spotty infestation of the 50 's and 60 's, but it later hindered the recognition 
of budworm as a long-term management problem associated with forest structure.

After 1976, perceptions began to change. As the spray program grew in size, reaching a maximum of 3.5 million acres (1.4 million hectares) in 1976, it also became necessary for the first time to treat large areas near settlements. In addition, the mandatory excise tax on all landowners, whether sprayed or not, was beginning to generate opposition, particularly among those landowners on the fringe of the outbreak area. The state and federal governments began to re-examine their financial contribution to the annual spray program, as concern about public financing increased.

On the legal front, the threat, and in some instances the initiation of actual law suits continued to hamper the effective administration of the spray program. The majority of suits were based on provisions of the National Environmental Policy Act (NEPA). In addition, challeges were made to the legal authority of the Maine Forest Service to carry out the program in conjunction with its state legislative mandate. At the local level several attempts were made to pass municipal ordinances prohibiting spraying.

To address these concerns, and in an attempt to develop a more effective budworm policy, a Spruce Budworm Policy Review Committee was established. The committee faced several key issues: (1) Should landowner participation in spraying be voluntary? What form of tax would best promote the reduced and efficient use of pesticides? (3) Who should administer the program? (4) What aspects of budworm management should receive state and federal support? (5) Should people be able to restrict spraying near their homes? (6) Should the budworm tax be based on ability to pay, i.e. should non-industrial landowners pay less?

The 1980 Spruce Budworm Management Act incorporated most of the committee's recommendations on these questions. The Act provided statutory support for the view of budworm as an ongoing forest management problem. A new system of voluntary participation and a tax based primarily on acres sprayed each year motivated landowners to take a hard look at their own management objectives. Landowners began to accept responsibility for integrating budworm management into overall forest management, and increased their budworm staffs. The Maine Forest Service accepted continued responsibility for administering the spray program and a statewide budworm survey and assessment effort, but with increased landowner participation. State contributions to spray project cost were eliminated and replaced by a commitment to ongoing budworm research. A settlement region was established along publicly maintained roads within which local communities were authorized to disallow the state control program.

The new law was based on a new perception of budworm as a natural component of the spruce-fir forest that is always present to some degree. Budworm control is not an isolated activity, but is an integral component of ongoing forest management. Different landowners, with different goals, will require different forest management strategies. Protection goals will vary, and some timber losses must be tolerated. Long term management is the responsibility of individual forest landowners. State action is needed for survey and detection over large mixed ownerships, for overseeing the protection program, and for research to develop improved management and control strategies.
The state funded budworm research program has played an integral role in developing Bacillus thuringiensis as an effective biological control agent for budworm, and in refining and improving spray techniques. Current efforts are being directed to developing cost effective techniques for thinning young forest stands, and better techniques for protecting red spruce.

Since passage of the 1980 Budworm Management Act, a primary focus of state policy has been on controlling the cost of the budworm spray program so as to maximize protected acreage. Despite these efforts some landowners have left the state program to establish their own budworm control programs, thereby reducing their protection costs and also providing greater flexibility of control over areas to be protected. In recent years public pressure for an all Bt spray program has increased. This year 30\% of the spray program acreage was treated with Bt. The major constraint on increased Bt use is its higher cost, though cost differentials are decreasing.

On the legal side, recent years have seen a decline in the number of law suits brought against the program, primarily due to withdrawal of federal funding support. Some localized efforts have been made to prevent the use of a municipal airport for spruce budworm control operations. These efforts have been unsuccessful and I expect as we move further towards a $\mathrm{Bt}$ or biological insecticide program that these concerns will be further reduced.

In short, we in Maine are at a critical decision point relative to the future health and productivity of our spruce and fir resources. Landowners must develop and implement longterm strategic investment programs in management actions that will optimize their own individual wood supply futures. The risks of investing in the new forest are large, there is no denying it. But, the risks of no action are larger and the implications more certain. A significant reduction in sustainable harvest is inevitable in the absence of more intensive management.

The limits of our uncertain knowledge will continue to plague decisionmakers. Several key questions remain to be answered:

1) Will the budworm outbreak collapse, or will it continue at some level into the foreseeable future, requiring ongoing investments in protection?

2) What unknown pest problems will develop with the "new forest", creating yet another level of risk?

3) How fast will forest industry respond to reduced tree size and quality? How will individual industrial transition strategies affect future wood prices?

Searching for answers to these and other questions will continue to challenge forest landowners, and state policy makers as they make decisions today that will determine the future health and productivity of the forest in the year 2020 . 